\title{
New Protein Sources in Adults Diet for Mass-rearing of Anastrepha fraterculus (Diptera:Tephritidae)
}

\author{
Renata Morelli ${ }^{1}$, Karen Zamboni Costa ${ }^{1}$, Kenya Martins Fagioni ${ }^{1}$, Maria de Lourdes \\ Zamboni Costa ${ }^{1}$, Antônio Souza do Nascimento ${ }^{2}$, Rodrigo Meirelles de Azevedo Pimentel ${ }^{3}$ \\ and Julio Marcos Melges Walder ${ }^{1 *}$ \\ ${ }^{1}$ Laboratório de Radioentomologia; Centro de Energia Nuclear na Agricultura; Universidade de São Paulo; Av. \\ Centenário, 303; C. P.: 96; 13400-970; Piracicaba - SP - Brasil. ${ }^{2}$ EMBRAPA Mandioca e Fruticultura; $R$. \\ Embrapa, $s / n^{o}$; 44380-000; Cruz das Almas - BA - Brasil. ${ }^{3}$ Empresa de Pesquisa Agropecuária de Minas Gerais; \\ Av. José Cândido da Silveira, 1647; 31920-007; Belo Horizonte - MG - Brasil
}

\begin{abstract}
The aim of this study was to find alternatives to reduce the cost of mass production of the South American fruit fly (A. fraterculus) by looking for locally available products as protein source in the diet of adults to replace the imported product without changing the quality parameters. Two yeast from a Brazilian company were evaluated. The quality parameters showed that the imported hydrolyzed yeast used in the adult diet could be perfectly replaced by the local products tested, with a reduction of over $80 \%$ of the cost of the diet. The quality of the produced insects remained the same and there were improvements in some quality parameters such as the volume of eggs produced, number of adults flying and longevity under the stress.
\end{abstract}

Key words: South American fruit fly, yeasts, aminoacids, insect nutrition, quality control

\section{INTRODUCTION}

Brazil occupies the third world's position in the ranking of fresh fruit exports (Anuário Brasileiro de Fruticultura 2009) and still has potential to grow. Nowadays one of the main factors that limits this expansion in the world market for fresh fruits is that Anastrepha fraterculus (Wiedemann) and other fruit flies are considered quarantine pests in important markets such as United States and Japan for the Brazilian fruits.

The first step to change this situation should be to set up the programs of area-wide integrated pest management (IPM), which should aim to entitle the main Brazilian fruit production regions the status of 'low prevalence area' of A. fraterculus and other species of fruit flies (ISPM 2006, Malavasi et al. 2007). The use of Sterile Insect Technique (SIT) in IPM programs has shown high efficacy to reach the population suppression of key pests in different crops (Klassen and Curtis 2005, Lance and McInnis 2005) that can also be used in a preventive way to the establishment of the pest in free areas or even to eradicate the species, depending on the region and objective of the program (Hendrichs et al. 2005). In the case of $A$. fraterculus which is a native species of Brazil, SIT should be used only to decrease this pest population to the lowest levels, because the eradication of this species may result in undesirable ecological impacts (Whitten and Mahon 1995). In many countries SIT is used in

*Author for correspondence: jmwalder@ cena.usp.br 
area-wide to the control of several species of fruit flies (Hendrichs et al. 2005). In Brazil, a program against the Mediterranean fruit fly (Ceratitis capitata) is being implemented with the use of SIT (Malavasi et al. 2007). The biofactory responsible for the supply of sterile insects is already in activity and forecasts massal production of $A$. fraterculus and other species such as Cydia pomonella (Lepidoptera:Tortricidae) and the larval parasitoid of fruit flies Diachasmimorpha longicaudata

(Malavasi et al. 2007).

To respond to the demand of insects for research programs and for the use of SIT in area-wide, it is necessary to mass rear these insects. Some Latin American countries such as Brazil, Argentina, Colombia and Peru in the last decade have worked on domestication and have established protocols for the mass rearing of $A$. fraterculus (Alama 1999, Buena and Dueñas 1999, Ortiz 1999, Salles 1999). These efforts resulted, some years later, in improvement of handling procedures and increased production levels (Jaldo et al. 2001, Vera et al. 2007). Recently, the Laboratory of Radioentomology of the Center for Nuclear Energy in Agriculture of the University of São Paulo (CENA/USP) has developed a protocol for artificial rearing of A. fraterculus and A. obliqua in Brazil for the production of large amounts of high quality eggs and pupae of these insects since 2007 (Costa et al. 2010).

Among many factors to consider when developing the mass rearing strategies, artificial diets may be considered as one of the most important components and, together with labor, they constitute the main costs. Therefore, in mass rearing, the search for cost reduction of diet is constant, always aiming a balance between the costs and insect quality. The use of local ingredients may guarantee the supply and, generally, reduce the production costs (Parker 2005). Most of the biofactories of fruit flies in the world uses, as a protein source in the diet of adults, hydrolyzed yeast (Saccharomyces cerevisiae) imported from the United States, resulting in high insect production costs. Searching for new protein sources, this study tested several local products and the promising ones were used in the mass rearing for nine consecutives generations using several batches of the proteins. The objective of this work was to evaluate the local sources of protein to be used in adults' diet of A. fraterculus that could substitute the expensive imported product without decreasing the quality parameters of mass reared flies.

\section{MATERIALS AND METHODS}

The experiment was conducted in acclimatized rooms $\left(24 \pm 1^{\circ} \mathrm{C}, \mathrm{RH} 65 \%\right.$ and photophase $\left.12 \mathrm{~h}\right)$. The pupae of $A$. fraterculus used in this experiment were from the artificial rearing of the Laboratory of Radioentomology of CENA/USP and were at their $30^{\text {th }}$ generation. The adults were kept in acrylic and aluminum cages $(150 \times 75$ x 30 $\mathrm{cm}$ ) with one of the side walls having a screen for ventilation and another made of a red cloth material like voile with a thin layer of silicon for oviposition (cages adapted for A. fraterculus and A. obliqua rearing, model CENA/USP). Foam attached to a transparent PVC lid was placed outside and parallel to the cloth with silicon without touching it, which was watered twice a day to avoid the drying of the eggs. Each cage received $200 \mathrm{ml}$ of pupae which corresponded to approximately 5.4 thousand adults.

Three protein sources (yeast Saccharomyces cerevisiae) were evaluated in three treatments: $\mathrm{T} 1$ $=$ yeast Bionis $\mathrm{YE} \mathrm{MF}^{\circledR}$ (Biorigin, Lençóis Paulista, São Paulo); T2 = yeast Bionis YE NS $^{\circledR}$ (Biorigin, Lençóis Paulista, São Paulo) and T3 = yeast YHE (Yeast Hydrolysate Enzymatic) (MP Biomedical LLC, Solon, Ohio, USA). The treatments $\mathrm{T} 1$ and $\mathrm{T} 2$ were alternatives protein sources to the imported yeast (T3). In addition to protein, the diet had wheat germ and sugar (proportion of 1:1:3, respectively) to provide the complete recipe.

Three adult cages were set up in the way described previously, each one for a treatment containing the diet with the respective protein source. Eight days after adult emergence, eggs begun to be collected daily for 10 days period, after which the cages were discarded. The experiment was in an unreplicated factorial design with randomized blocks (batch of egg collection). The procedures for egg collection and all the other procedures used until the emergence of adults were the same used in the artificial rearing (Walder 2002).

\section{Variables analyzed}

Volume and viability of eggs

The entire volume of eggs was measured and after $48 \mathrm{~h}$ of aeration, a sample of approximately 100 eggs was removed and placed over a black filter 
paper moistened inside a Petri dish. Larvae and eggs were counted and the larvae were removed. The dishes were placed at $25^{\circ} \mathrm{C}$. After $48 \mathrm{~h}$, the egg hatch was recorded. The viability of eggs was determined by the following formula: [(number of eggs + number of larvae - number of hatchings)/ (number of eggs + number of larvae)]. The eggs were collected for 10 consecutive days.

\section{Larval viability}

One hundred larvae newly hatched from the six first egg collections $(n=6)$ were distributed over $100 \mathrm{ml}$ of diets in plastic trays $(13 \times 13 \times 5 \mathrm{~cm})$. After 10-13 days, the third instar larvae were removed from the diet and placed in the vermiculite for pupation. The number of pupae recovered was recorded.

\section{Weight and volume of pupae}

From each batch of egg collection, the samples of 100 pupae were randomly separated, weighed and the volume was measured to determine the mean weight and volume of 100 pupae.

\section{Egg-pupae recovery}

From each batch of egg collection, $0.3 \mathrm{ml}$ were placed on $300 \mathrm{ml}$ of artificial diet for larval development. Third instar larvae were removed from the diet for pupation and the volume of pupae collected was measured. Considering that $1.0 \mathrm{ml}$ of eggs had 11700 eggs and $1.0 \mathrm{ml}$ of pupae has 30 pupae, the egg-pupae recovery was calculated by the following formula: (volume of collected pupae $x$ 30)/ volume of eggs seeded x 11700).

\section{Adult emergence, sex ratio and cycle duration}

One hundred pupae from each batch of egg collection were placed in $500 \mathrm{ml}$ plastic pots with perforated lids, and after $72 \mathrm{~h}$, the number of males and females emerged was recorded. Cycle duration (from the egg to adult) was considered as the number of days between the eggs collecting date and its respective date of emergence. Sex ratio was calculated as the number of females/ number of adults.

\section{Flight ability}

It was determined according to the methodology proposed by FAO/IAEA/USDA (2003) for the samples of 100 pupae for each batch of egg collection. The result was expressed as the number of flying insects corresponding to the following formula: [number of pupae - (number of insects not emerged + number of insects semi-emerged + adults unable to fly)].

\section{Longevity under stress}

It was evaluated by confining 100 pupae from each batch of eggs collection in transparent plastic pots of $500 \mathrm{ml}$, without food or water. After $48 \mathrm{~h}$ of adult emergence, the daily counting of fly mortality started.

\section{Data analysis}

All the parameters, except longevity, were analyzed by un-replicated factorial ANOVA as the data followed normal distributions and the variances were equal. In case of significance of the analysis, the means were compared by Tukey HSD test $(P<0.05)$. The longevity under stress was evaluated using the Kaplan-Meier estimator in which the curves were compared by the pairs by the log-rank test with Bonferroni's correction. The entire analysis was made using the statistic pack $\mathrm{R}$ version 2.10.1( $R$ Development Core Team 2009).

\section{RESULTS}

The local protein sources in the diet given to the adults of $A$. fraterculus provided, in general terms, the same results of the imported protein for most of the variables analyzed, and in some cases a better performance (Table 1).

The entire volume of daily egg's collection differed between the treatments $\left(\mathrm{F}_{(2,18)}=3.78\right.$, $P=0.04)$ and the highest value came from a local source of protein, but their viability (fertility) was not influenced by the sources $\left(F_{(2,18)}=0.77\right.$, $P=0.48)$. The viability of larvae varied with the source of protein available $\left(\mathrm{F}_{(2,10)}=10.31, P<0.01\right)$. The larval recovery was equal between the two local protein sources and both differed from the imported yeast, which presented the lowest larval recovery.

The weight and volume of pupae did not differ between the treatments $\left(\mathrm{F}_{(2,18)}=0.31, P=0.74\right.$ and $\mathrm{F}_{(2,18)}=0.25, P=0.78$, respectively) so as the eggpupae recovery $\left(\mathrm{F}_{(2,18)}=0.36, P=0.70\right)$. The adult emergence of the progeny were equal to all different treatments given to the adults $\left(\mathrm{F}_{(2,18)}=1.47, \quad P=0.25\right)$. However, progeny flight ability varied with the different sources of protein in the diet $\left(\mathrm{F}_{(2,18)}=4.00, P=0.04\right)$, the diet with imported yeast resulted in less adult fliers compared to the local alternatives that did not 
differ between themselves. The different sources of protein in the diet did not alter the sex ratio of the progeny $\left(\mathrm{F}_{(2,18)}=2.61, P=0.10\right)$, which varied between 65 and $61 \%$ of females, neither the duration of the cycle between the egg to adult $\left(\mathrm{F}_{(2,18)}=0.04, P=0.95\right)$.

The longevity of the adult progeny under the stress (i.e. deprived from water and food) was different depending on the source of protein given to the parents $\left(\chi_{(2,29)}^{2}=980, P<0.0001\right)$
(Fig. 1). Two of the diets with local protein (T1 and T2) showed the highest percentages of adults alive at the third day after the emergence $(72 \% \pm 0.01$ and $67 \% \pm 0.01$ for $\mathrm{T} 1$ and $\mathrm{T} 2$ respectively). The imported protein resulted in $64 \% \pm 0.01$ of survival at the third day. All the treatments differed between themselves $(P<0.0001)$.

Table 1 - Biological parameters of $A$. fraterculus in artificial rearing with three adults diet differing in the protein source. Mean \pm SE $(\mathrm{N})$.

\begin{tabular}{|c|c|c|c|c|}
\hline \multirow{2}{*}{ Parameters } & \multicolumn{3}{|c|}{ Treatments $^{1}$} & \multirow{2}{*}{$P$} \\
\hline & T1 & $\mathbf{T} 2$ & $\mathbf{T 3}$ & \\
\hline Volume of eggs (ml) & $1.25 \pm 0.13(10) \mathrm{a}$ & $1.08 \pm 0.08(10) \mathrm{ab}$ & $1.06 \pm 0.12(10) b$ & $0.0426 *$ \\
\hline Egg viability (\%) & $71.35 \pm 2.14(10) \mathrm{a}$ & $71.65 \pm 2.32(10) \mathrm{a}$ & $68.21 \pm 1.97(10) \mathrm{a}$ & 0.4792 \\
\hline Larval viability (\%) & $65.17 \pm 6.61(6) \mathrm{a}$ & $66.33 \pm 5.56(6) \mathrm{a}$ & $51.67 \pm 7.25(6) b$ & $0.0037 *$ \\
\hline Weight of 100 pupae (g) & $1.58 \pm 0.04(10) \mathrm{a}$ & $1.59 \pm 0.05(10) \mathrm{a}$ & $1.60 \pm 0.05(10) \mathrm{a}$ & 0.7365 \\
\hline Volume of 100 pupae (ml) & $3.44 \pm 0.09(10) \mathrm{a}$ & $3.45 \pm 0.00(10) \mathrm{a}$ & $3.40 \pm 0.12(10) \mathrm{a}$ & 0.7822 \\
\hline Egg-pupae recovery & $29.32 \pm 3.50(10) \mathrm{a}$ & $26.67 \pm 4.92(10) \mathrm{a}$ & $26.97 \pm 5.15(10) \mathrm{a}$ & 0.7014 \\
\hline Emergence $(\%)$ & $90.30 \pm 1.64(10) \mathrm{a}$ & $90.08 \pm 1.61(10) \mathrm{a}$ & $87.30 \pm 2.27(10) \mathrm{a}$ & 0.2559 \\
\hline Flying insects $(\%)$ & $87.70 \pm 1.43(10) \mathrm{a}$ & $87.10 \pm 1.68(10) a$ & $81.60 \pm 2.42(10) b$ & $0.0364 *$ \\
\hline Sex ratio & $0.35 \pm 0.02(10) \mathrm{a}$ & $0.37 \pm 0.02(10) \mathrm{a}$ & $0.40 \pm 0.01(10) \mathrm{a}$ & 0.1007 \\
\hline Cycle egg: adult (days) & $28.90 \pm 0.48(10) \mathrm{a}$ & $29.00 \pm 0.44(10) \mathrm{a}$ & $29.10 \pm 0.43(10) \mathrm{a}$ & 0.3874 \\
\hline
\end{tabular}

${ }^{1} \mathrm{~T} 1=$ yeast Bionis $\mathrm{YE} \mathrm{MF}^{\circledR}$ (Biorigin); T2= yeast Bionis YE NS ${ }^{\circledR}$ (Biorigin) and T3= imported yeast (MP Biomedical LLC). Means followed with the same letter in the row did not differ between themselves ( $P>0.05$, Tukey's test).

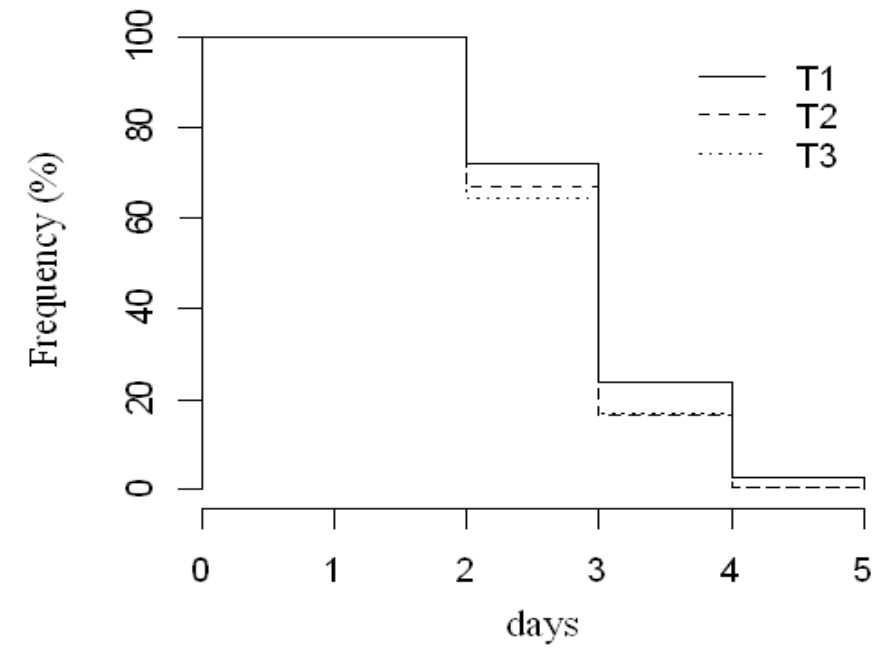

$\mathrm{T} 1=$ yeast Bionis YE MF (Biorigin); $\mathrm{T} 2=$ yeast Bionis $\mathrm{YE} \mathrm{NS}^{\circledR}$ (Biorigin) and $\mathrm{T} 3=$ imported yeast (MP Biomedical LLC).

Figure 1 - Survival, under stress condition, of adults of $A$. fraterculus out from parents fed on diets with different sources of protein. Estimate accord the method of Kaplan-Meier. 


\section{DISCUSSION}

There were improvements in the parameters such as egg production, larval viability, flight ability and longevity under stress conditions diets were used with local yeast extracts. The whole diets contained, besides the difference source of protein, sugar and wheat germ. The availability of vitamins in the diets of adults of Tephritidae, mainly the lipid soluble ones, could interfere in egg production (Tsiropoulos 1980; Kaur and Srivastava 1991, Chang et al. 2001). However, wheat germ in the diet supplies vitamins (A, E and B-complex) and lipids for all the treatments (Chang and Vargas 2007). Nevertheless, the local protein Bionis YE $\mathrm{MF}^{\circledR}$ (Biorigin) increased the egg production and such improvement might have been due to protein profile instead of carbohydrates, lipids or vitamins.

Both yeast Bionis YE $\mathrm{MF}^{\circledR}$ (Biorigin) and yeast Bionis YE NS ${ }^{\circledR}$ (Biorigin) extracts had $64.5 \%$ of protein, whereas in the imported hydrolyzete, it was $60 \%$. However, this difference could be barren once the flies had free access to the food. The aminogram of the different extracts (Table 2) showed that the three protein sources had all the assential amino acids: arginine, histidine, isoleucine, leucine, lysine, methionine, phenylalanine, threonine, tryptophan and valine (Gilmour et al. 2005). The main difference among the aminograms was that the imported yeast (T3) did not contain cystine. Cystine is an amino acid considered not-essential for most insects and is composed by two cysteine molecule connected by a disulfide bond. It is also an important source of SH groups in the animals (Gilmour et al. 2005). Many organisms, including the insects, can synthesize cysteine from methionine and therefore generally, it is not required in a diet when methionine is provided (Gilmour et al. 2005). However, the necessary amount of methionine for the development of insects may be saved by supplying cysteine considering that the path of cysteine synthesis from methionine is reversible in the insects (Dadd 1985).

Since the diet that resulted in less larval viability and less number of adult flyers was the one with hydrolyzed yeast that did not contain cystine (Table 2), possibly this amino acid had an important role, but not restrictive, in the physiological processes essential to the development of $A$. fraterculus.

Table 2 - Aminogram of yeast used as protein source for the feeding of A. fraterculus adults in mass rearing.

\begin{tabular}{cccc}
\hline Aminoacids & Bionis $\mathbf{Y E ~} \mathbf{M F}^{\circledR}(\mathbf{T 1})$ & Bionis $^{\circledR} \mathbf{E ~ N S} \mathbf{( T 2}^{\circledR} \mathbf{T}$ & YHE(T3) \\
\hline Alanine & 4.78 & 5.78 & 4.68 \\
Arginine & 4.13 & 5.02 & 4.04 \\
Aspartic acid & 7.94 & 6.41 & 3.21 \\
Glycine & 3.31 & 3.03 & 2.88 \\
Isoleucine & 3.63 & 3.14 & 4.36 \\
Leucine & 5.05 & 4.30 & 8.78 \\
Glutamic acid & 8.36 & 11.05 & 4.81 \\
Lysine & 5.31 & 5.04 & - \\
Cystine & 0.77 & 0.96 & 1.09 \\
Methionine & 0.90 & 1.18 & 2.69 \\
Phenylalanine & 2.91 & 2.53 & 2.24 \\
Tyrosine & 2.04 & 2.27 & 2.88 \\
Threonine & 3.46 & 2.90 & 0.64 \\
Tryptophan & 0.61 & 0.47 & 3.08 \\
Proline & 2.31 & 2.34 & 3.53 \\
Valine & 4.50 & 4.02 & 1.60 \\
Histidine & 1.41 & 1.30 & 3.08 \\
Serine & 3.14 & 2.72 & 60.00 \\
TOTAL & 64.56 & 64.46 & \\
\hline
\end{tabular}

From Biorigin and MP Biomedical LLC quality control certificate. 
Despite the difference in the composition of amino acids in the adults' diet, larval diet was the same for all the treatments. Aedes spp. grow slightly better with diets with cystine in their composition, together with the right dose of methionine (Dadd 1985), and its lack negatively affects the process of ecdysis and adult emergence. (Gilmour et al. 2005). The availability of cystine to the females during egg formation could result in neonate larvae with more capacity of larval development, because this amino acid influences the ecdysis process (Gilmour et al. 2005).

Understanding the effects of parents feeding in flying adults of the progeny seems more difficult because they are distant phases. The possibility that with the adequate supply of methionine for the embryos the use of cystine may be saved (Dadd 1985), and the adequate supply during the larval development compensates any deficiency during the adult stage, may result in more flying insects, as cystine is present in the constitution of bursicon, a polypeptidic hormone responsible for cuticle sclerotization and wings expansion of the insects (Dewey et al. 2004, Luo et al. 2005). Alteration in the synthesis of bursicon's polypeptides could not complete the wings and thorax expansion and kept the bristles overlapped in Drosophila melanogaster mutants (Dewey et al. 2004). Chang (2004) did not find difference between the flying adults of $C$. capitata fed with diet without cystine. This difference could have been the result of the methodology; the used adults with more than one day old were fed with the tested diets before the flying test. In the present study, flight ability was evaluated in the progeny immediately after the adult emergence.

All plausible justifications and hypothesis hereby discussed about the results were in fact speculations based on the literature, since this study did not have as an objective the elucidation of the amino acids participation on insect physiology. Therefore, the methodology was unable to support such findings. Thus, future studies are necessary to better understand the amino acids role in quality improvement of mass reared fruit flies. In spite of this, the present study provided some basis to further studies aiming at uncover the physiological needs for this species.

From a practical point of view, this study provided relevant information. Artificial diets represent one of the main costs of insect mass production
(Parker 2005). The production cost of 1 million adults of $A$. fraterculus at the Laboratory of Radioentomology of CENA-USP, using imported protein was US\$ 82.01 whilst the same amount of insects could be obtained at US\$ 8.42 with locally available yeast. This represents savings up to $89.73 \%$ in the adults diet and up to $31.14 \%$ in the overall diets cost (adults and larvae).

Thus, the imported hydrolyzed yeast used in the diet of adults of $A$. fraterculus (and other fruit flies) could be perfectly replaced by the local products tested in the diet for A. fraterculus, reducing in more than $80 \%$ the cost of diet, and without any negative effect on quality parameters.

\section{REFERENCES}

Alama D. Ensayos para determiner niveles de oviposicion de Anastrepha fraterculus (Wied.) sobre fruta y dispositivos artificiales. In: Proceedings of a workshop organized by the Joint FAO/IAEA Division of Nuclear Techniques in Food and Agriculture. Viña del Mar, Chile. IAEA-TECDOC-1064; 1999. p. 7983.

Anuário Brasileiro de Fruticultura. Gazeta, Santa Cruz do Sul. 2009.

Buena LD, Dueñas RG. Avances sobre la cria artificial de Anastrepha fraterculus (Wied.) (Diptera:Tephritidae) en Colombia. In: Proceedings of a workshop organized by the Joint FAO/IAEA Division of Nuclear Techniques in Food and Agriculture. Viña del Mar, Chile. IAEA-TECDOC1064; 1999. p. 85-94.

Chang CL. Effect of Amino Acids on Larvae and Adults of Ceratitis capitata (Diptera: Tephritidae). Ann. Entomol. Soc. Am. 2004; 97: 529-535.

Chang CL, Vargas RI. Wheat germ oil and its effects on a liquid larval rearing diet for oriental fruit flies (Diptera: Tephritidae). J. Econ. Entomol. 2007; 100: 322-326.

Chang CL, Albrecht C, El-Shall SSA, Kurashima R. Adult reproductive capacity of Ceratitis capitata (Diptera: Tephritidae) on a chemically defined diet. Ann. Entomol. Soc. Am. 2001; 94: 702-706.

Costa KZ, Faggioni KM, Lima FTW, Kamya AC, Rocha ACP, Morelli R, et al. Criação de Anastrepha obliqua Macquart, 1835 (Diptera:Tephritidae) em dieta artificial In: CD Resumos. Simpósio científico dos pós-graduandos no Cena/USP, Piracicaba, 2010.

Dadd RH. Nutritional organisms. In: Kerkut GA, Gilbert LI. Comprehensive insect physiology biochemistry and pharmacology. Volume 4, Pergamon Press. 1985. p. 313-390. 
Dewey EM, McNabb SL, Ewer J, Kuo GR, Takanishi CL, Truman JW, et al. Identification of the gene encoding bursicon, an insect neuropeptide responsible for cuticle sclerotization and wing spreading. Curr. Biol. 2004; 14: 1208-1213.

FAO/IAEA/USDA. Manual for product quality control and shipping procedures for sterile mass-reared Tephritid fruit flies, Version 5.0, Vienna: IAEA; 2005.

Gilmour D. The biochemistry of insects. New York: Academic Press; 1969.

Hendrichs J, Vreysen MJB, Enkerlin WR, Cayol JP. Strategic options in using sterile insects for area-wide integrated pest management. In: Dyck VA, Hendrichs J, Robinson AS.Sterile insect technique: principles and practice in area-wide integrated pest managemen. Dordrecht: Springer; 2005. p. 563-600.

ISPM 26. Establishment of pest free areas for fruit flies (Tephritidae). Rome: IPPC, FAO. 2006.

Jaldo HE, Gramajo MC, Willink E. Mass rearing of Anastrepha fraterculus (Diptera: Tephritidae): a preliminary strategy. Fla. Entomol. 2001; 84: 716718.

Kaur S, Srivastava BG. Effect of B-vitamins on various parameters of reproductive potential of Dacus cucurbitae (Coquillett). Indian J. Entomol. 1991; 53: 543-547.

Klassen W, Curtis CF. History of the sterile insect technique. In: Dyck VA, Hendrichs J, Robinson AS.Sterile insect technique: principles and practice in area-wide integrated pest managemen. Dordrecht: Springer; 2005. p. 3-36.

Lance DR, McInnis DO. Biological Basis of the Sterile Insect Technique. In: Dyck VA, Hendrichs J, Robinson AS.Sterile insect technique: principles and practice in area-wide integrated pest managemen. Dordrecht: Springer; 2005. p. 69-94.

Luo CW, Dewey EM, Sudo S, Ewer, J, Hsu SY, Hener Gger HW, et al. Bursicon, the insect cuticle-hardening hormone, is a heterodimeric cystine knot protein that activates $\mathrm{G}$ protein-coupled receptor LGR2. PNAS, 2005;102: 2820-2825.

Malavasi A, Zucchi RA, Sugayama RL. Biogeografia. In: Malavasi A, Zucchi RA. Moscas-das-frutas de importância econômica no Brasil: conhecimento básico e aplicado. Ribeirão Preto, Holos Editora; 2000. p. 93-98.

Malavasi A, Nascimento AS, Paranhos BJ, Costa MLZ, Walder JMM. Establishment of a Mediterranean fruit fly Ceratitis capitata, fruit fly parasitoids, and codling moth Cydia pomonella rearing facility in northeastern Brazil. In: M.J.B. Vreysen MJB, Robinson AS, Hendrichs J. Area wide control of insect pests: from research to field implementation, Dordrecht: Springer; 2007. p. 175-182.
Ortiz G. Introduction. In: Proceedings of a workshop organized by the Joint FAO/IAEA Division of Nuclear Techniques in Food and Agriculture. Viña del Mar, Chile, IAEA-TECDOC-1064; 1999. p. 1-2.

Parker AG. Mass-rearing for sterile insect release. Biological Basis of the Sterile Insect Technique. In: Dyck VA, Hendrichs J, Robinson AS.Sterile insect technique: principles and practice in area-wide integrated pest managemen. Dordrecht: Springer; 2005. p. 209-232.

R Development Core Team. R: A language and environment for statistical computing. Vienna: $\mathrm{R}$ Foundation for Statistical Computing; 2009. [accessed on Jun 2011] Available from: www.R-project.org.

Salles LAB. Metodologia de criação de Anastrepha fraterculus (Wied., 1830) (Diptera: Tephritidae) em dieta artificial em laboratório. An. Soc. Ent. Brasil, 1992; 21: 479-486.

Salles LAB. Rearing of Anastrepha fraterculus (Wiedemann). In: Proceedings of a workshop organized by the Joint FAO/IAEA Division of Nuclear Techniques in Food and Agriculture. Viña del Mar, Chile, IAEA-TECDOC-1064; 1999. p. 95100.

Tsiropoulos GJ. The importance of vitamins in adult Dacus oleae (Diptera:Tephritidae) nutrition. Ann. Entomol. Soc. Am. 1980; 73: 705-707.

Vera MT, Abraham S, Oviedo A, Willink E. Demographic and quality control parameters of Anastrepha fraterculus (Diptera: Tephritidae) maintained under artificial rearing. Fla. Entomol. 2007; 90: 53-57.

Walder JMM. Produção de moscas-das-frutas e seus inimigos naturais: associação de moscas estéreis e controle biológico. In: Parra JRP, Botelho PSM, Corrêa-Ferreira BS, Bento JMS. Controle Biológico no Brasil: Parasitóides e predadores. São Paulo: Manole; 2002. p.181-190.

Whitten M, Mahon R. Misconceptions and constraints. . In: Dyck VA, Hendrichs J, Robinson AS. Sterile insect technique: principles and practice in area-wide integrated pest managemen. Dordrecht: Springer; 2005. p. 601-626.

Received: December 22, 2010; Revised: May 17, 2011; Accepted: August 06, 2012. 


\section{PAGINA EM}

BRANCO 